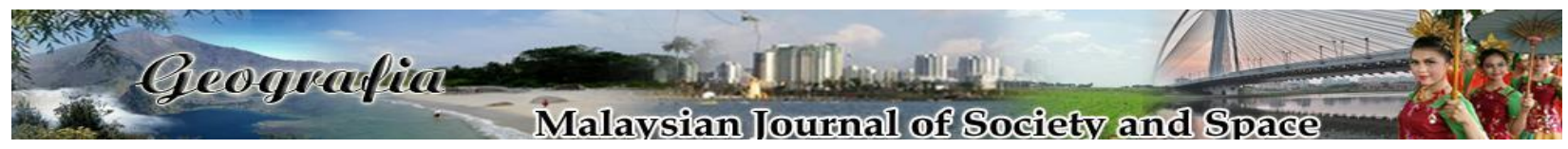

\title{
Overview of Colonial Development Policy on Malayan pineapples industry, 1926-1934
}

\author{
Mohd Shazwan Mokhtar, Mohd Samsudin, Suffian Mansor \\ Research Centre for History, Politics and International Affairs, \\ Faculty of Social Science and Humanities, Universiti Kebangsaan Malaysia \\ Correspondence: Mohd Shazwan Mokhtar (email: msm@ukm.edu.my)
}

Received: 03 May 2020; Accepted: 20 January 2021; Published: 27 February 2021

\begin{abstract}
During the inter-war years, the Colonial Empire played a significant role in contributing tropical products to the United Kingdom. Besides supplying raw materials, the colonies also contribute to the food supply for the mother country's inhabitants. In 1925, the Imperial Economic Committee began promoting and inquiring the empire's food product for consumption in the United Kingdom. Afterwards, the British government introduced the Colonial Development Act of 1929 to encourage tropical development in the Colonial Empire. However, the present study neglected the influence of that on Malayan economic activities. Thus, this article examines the implementation of the colonial development policy in promoting Malayan pineapples industry. This study used content analysis to construct the relationship between colonial policy and economic development in Malaya. This study provides historical evidence and data collected from the National Archives of the United Kingdom and Malaysia's National Archives. The findings showed that the imperial aid had supported Malaya in becoming a major supplier for canned pineapples in the British Empire. However, the colonial development policy led the colonial government in Malaya as the debtor to the imperial government.
\end{abstract}

Keywords: British empire, colonial empire, economic history, global trade, neomercantilism, tropical fruits.

\section{Introduction}

Tropical colonies are a part of the British Empire that dependent upon agricultural production $(\mathrm{CO}$ 885/29/6, 1927). Also known as a Colonial Empire, the British possession in tropics is vast from the Caribbean, Africa to Asia and across large stretches of the Pacific Ocean. The tropical colonies comprised 1.8 million square miles, compared to Great Britain with 94,000 square miles. In 1956, the Colonial Empire consist of 87.7 million population, which is more than the mother country that holds 50.2 million (Havinden \& Meredith, 1993). Since the late nineteenth-century, the 
Colonial Empire supplied raw materials for the mother country. It was also the alternative market in avoiding the unpleasant economic competition in Europe, especially between the United States and Germany (Constantine, 1984). The imperial government attitude in this matter much influenced by the rise of British nationalism in rivalries with the foreign power to secure Britain's monopoly in global economic relation. Thus, the so-called new imperialist began attacking laissezfaire and revived the neomercantilism to seek imperial self-sufficiency through the Colonial Empire's exploitation (Madden, 1959). Recognised as the neo-mercantilist, Joseph Chamberlain, the Secretary of States for Colonies (1895-1903) had laid the early policy to encourage the imperial aid for the development of tropical products in the Colonial Empire. Chamberlain believed that the tropics would benefit the metropolis economy by developing colonial markets and raw materials sources (Constantine, 1984). In the 1920s, Chamberlain's policy influenced the colonial development policy that made the Colonial Empire a privilege commercial space. This policy focused on exploiting colonies' raw materials as the surest foundation for strengthening imperial bonds (Tomlinson, 2012).

Before the 1920s, the Colonial Stocks Acts of 1877-1900 only empowered trustees in Britain to invest in colonial inscribed stocks (Jessop, 1976). The law enabled the colonial government to borrow a loan in the London market at lower interest rates. However, the specific assistance for development and welfare was introduced during Chamberlain tenure in Colonial Office. He promogulated the imperial aid to develop tropical medicine and the West Indies' reconstruction (British Aid-5, 1964). Next, the policy became significant in solving the post First World War economic downturn and unemployment crisis. In 1929, the British Parliament passed the Colonial Development Act to aid and develop agriculture and industries in the tropical colonies. The scheme involves the Crown Colonies, Protectorates and Mandated Territories, to promote commerce with or industry in the United Kingdom. Yet, because of too much concentration on the "scramble for Africa", this paper commits to lead the overview of the 1929 Colonial Development Act's sway in developing Malaya (Meredith, 1975).

\section{Literature review}

The early works on Malaya (Malaysia) economic history neglected the imperial government influence in the tropical development policy during the inter-war years. This limitation has narrowed the Malaya economic historiography to laissez-faire or free trade framework. The current book by Sultan Nazrin Shah (2019) described the colonial government in Malaya encouraged free trade with minimal intervention in regulating the economy. Nevertheless, the book does not denounce the colonial government intervention role favouring British companies' interest. But he still analyzing the Malaya economic phenomenon before 1957 in laissez-faire framework. However, the finding lacks the global economic aspect. Palen (2016) and Tomlinson (2003) found that in the 1920s, a protectionist policy had won over free traders. The imperial economic policy started paying attention to empire integration and formed mercantilist control over the empire economic relations (Osterhammel, 2014).

Also, Drabble (1974) and Wong (1979) had shown the retreat of laissez-faire policy in Malaya by proving metropolitan intervention in the Malaya economy. The London controls on Malaya economic activities was clearly when the colonial government start developing the export economy (mainly rubber and tin) to meet the home industries demand. Wong (1979) asserted that; 
by the outbreak of the First World War, the basic pattern of the Malayan export economy had been evolved and set... when protectionism seriously undermined international free trade, the British, ... chose to protect their own industries by imposing import quotas and to restrict tin and rubber production that benefited Malaya's less efficient rivals.

Despite that, the authors' work bounded with the domestic discussion, which is needed to collaret with the imperial economic policy. Yet, Drabble (1974) writing has led this article to explore more on imperial government arrogated in Colonial Empire from 1914 onwards. However, his argument on laissez-faire was brought during the post-war need reevaluate. This is because Loh (2002) had found the British government adopted the imperial preference during the inter-war years. Besides, Mokhtar, Samsudin \& Azmi (2017) had proved the imperial preference was implemented as early as the year 1902. Wong (1979) acknowledged the research gaps in Malaya economic history by emphasizing the failure to use official records at the Public Record Office in London (now The National Archives) and the Malaysian archives. Also, Drabble (1974) added that further research would doubtlessly modify particular aspects of his paper's interpretations, which justifies this article's discussion.

Loh (2002) had contributed extensive research on colonial development policy by the British government for the Colonial Empire. She constructed that Malaya was influenced by the global economy's economic changes, which led to the Malayan colonial government maintained the primary commodities economic structure. Yet, her argument on "the colonial government was not particularly sympathetic to initiatives to start new industries" can be considered since the colonial government was trapped with the financial insufficiency to accommodate the export economy operational cost (Mokhtar, 2019). Meredith (1975) and, Havinden \& Meredith (2002) explained that the introduction of Colonial Development Act of 1929 helped the Malaya to develop new tropical product industries (mainly palm oil and pineapple) to meet the empire foodstuff market. However, the study on how the colonial development policy affected the Malayan pineapple development still underdeveloped. Thus, this article explores the imperial aid through the colonial development policy toward the development of Malayan pineapple industry.

\section{Method and study area}

The research used qualitative methodology in analysing primary and secondary sources to prove historical facts (Azlizan \& Salbiya, 2020). The primary sources ware collected at The National Archives, London and the Malaysia National Archives. Both institutions possessed official documents such as colonial records, government reports, original correspondences, and newspapers. They were analyzed and interpreted during constructing the historical context and creating a new dataset to support the argument (Collins, 2018). Simultaneously, the secondary sources (particularly books and journal) were used to understand the constant data in the primary sources. The wide range of primary sources also improved the research novelty and historical insight. The methodology was chosen to illustrate the past economic practice and phenomenon using historical evidence (Godden, 2015). 


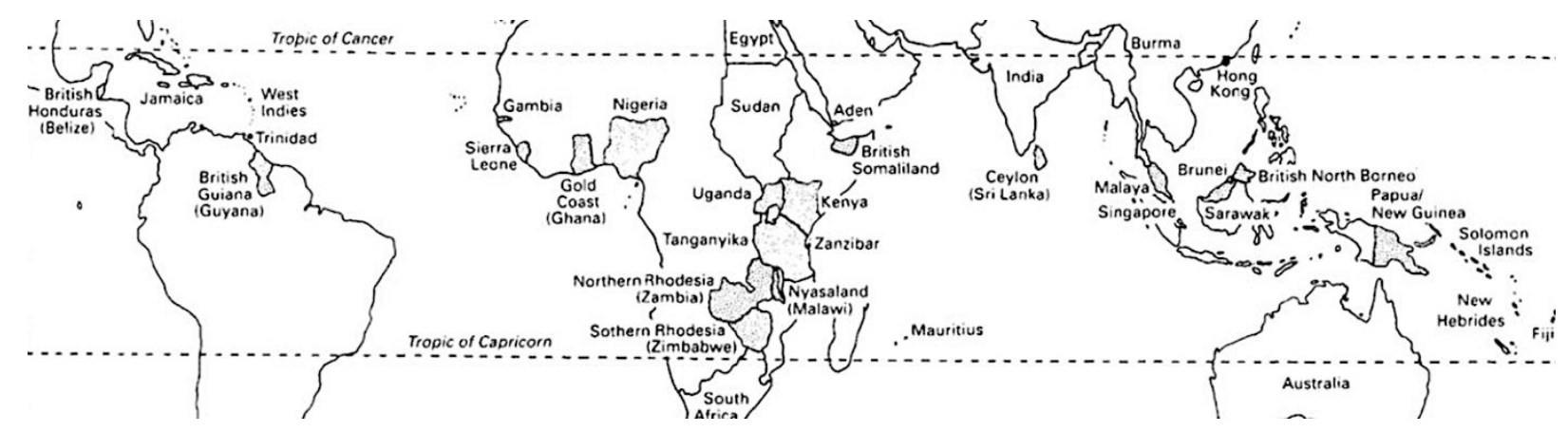

Source: Modified from Havinden \& Meredith (2002)

Figure 1. Tropical Colony in the British Colonial Empire

The study area is the British tropical dependencies in the Colonial Empire, as illustrated in Figure 1. However, the study focusing on Malaya as a leading centre for raw material supply in the Colonial Empire. The political and economic units that included in Malaya geography are the Federated Malay States (FMS), Unfederated Malay States (UMS) and Straits Settlements (SS). Until 1935, the tropical features of Malaya's climate are uniform temperature, high humidity and copious rainfall, and arise mainly from the maritime expose of the Peninsula. The daily range of temperature is generally between $10^{\circ}$ and $15^{\circ} \mathrm{F}$. at coastal stations and between $15^{\circ}$ and $20^{\circ} \mathrm{F}$. at inland stations. The variation of temperature throughout the year is minimal and excessive temperatures found in continental tropical areas are never experienced (FMS, 1936).

\section{Results and discussion}

\section{Imperial Economic Policy for the Colonial Empire}

In the 1920s, the development of imperial economic policy influenced by Chamberlain's vision to integrate the imperial economic relation (Ashton and Stockwell, 1996). The reason was that the post First World War depression caused a declining trend in global consuming power. This economic phenomenon caused the British's export to fall in the European market. Besides, depression also created unemployment in the United Kingdom (New Zealand, 1921). Thus, in late 1922, the loan for empire development focused among British officials for colonial economic development (Drummond 1974). The scheme aimed to increase the demand for British manufactured goods by developing a colonial market, which will also relieve Britain's unemployment. Accordingly, the British government initiated the Imperial Economic Conference to foster economic cooperation with the empire's colonial government (Constantine 1984). During the 1921's conference, Winston Churchill, the current Secretary of States for the Colonies, announced that the modern world could not get on without the commodities (rubber and tin) from Malaya (New Zealand, 1921). Realizing Malaya and other tropics colonies important role in the colonial market, Churchill successor, V.C. Cavendish and Lloyd Graeme, the President for Britain Board of Trade, introduced the first financial assistance scheme to accelerate the imperial resources in 1923 (CAB 24/158/CP/90, 1923).

Britain's dependence on the Colonial Empire became crucial when Stanley Baldwin, the Prime Minister of the United Kingdom, insisted on the empire cooperation to stimulate the interempire trade in 1923's Imperial Conference. Baldwin emphasized the need to revival the mother 
country's trade with her empire due to European economic condition weakness. Baldwin argued that,

I think you will agree that one of the most important items on it is this question of inter-imperial trade... I am confident that we shall be able to devise measure which will be to our mutual advantage by way of redistributing the population, improving transport and means of communication, and, generally, increasing the facilities for the growth of trade within the Empire (Imperial Conference 1923, 1924).

However, even the British Empire possessed unlimited resources; it still needs rapid development to meet the home demand. Therefore, the British government instructed the Colonial Office to counter the general depression of trade within the empire, mostly the tropical colonies, by fostering their development. The imperial government also planned to frustrate the Germany recovery after the First World War due to the Huns action controlling Britain's commodities supplies during the war prosecution (Constantine, 1984). Based on the situation, the 1923's Imperial Conference agreed with Cavendish and Graeme's scheme. Still, the financial assistance only came in term of the loan which later the colonial government need to pay it back to the imperial government with the interest of 0.75 per cent within five years (Imperial Conference 1923, 1924). Besides Malaya, the other tropics involved are Ceylon, Gold Coast, Kenya and Nigeria. Thus, a total of $£ 2,053,431$ loan provided for the developing railway facility and $£ 1,069,000$ for the development of ship dock in the FMS, while $£ 984,431$ allocated for the development of Johor causeway (CAB 24/158/CP/90, 1923).

After the separation between Colonial Office and Dominion Office in 1925, the Imperial Conference of 1926 builds a new cooperative unit for the empire's economic expansion with the Crown Colonies, Protectorates and Mandate Territories as the Colonial Empire (Malaya Tribune, 1928). During the Colonial Office Conference in 1927, the Colonial Empire defined as any British dependencies located in tropics or sub-tropics (CO 885/29/6, 1927). At the same conference, Leo Amery, the Secretary of State for the Colonies (1924-1929) introduced the tropical development policy for the Colonial Empire. The policy purposed to developing tropical products which cannot produce elsewhere except the colonies. Following this, the Colonial Empire became the suppliers for tropical products to the temperate zones (New Zealand, 1927). To ensure the exploitation, the British government directly controlled the colonial production and trade (Meredith, 1975).

In 1925, the British government, Dominion and India appointed the Imperial Economic Committee (IEC) to inquire about the empire's food products market (Sel. Sec. 2613/1925, 1925). The committee found that the inter-empire trade for fruit grew to $£ 44.8$ million in 1924 , which three times higher in 1913. Thus, IEC encouraged British manufacturers to invest in fruit production in the Colonial Empire. The committee expected this measure would increase the demand for the British producers' products by promoting fruit consumption from the colonies. Besides, the United Kingdom can reduce the dependence of fruit imports from foreign countries. Among fruits proposed for development were apple, citrus fruit, nut, banana and pineapple (CO 273/534/15, 1926).

\section{Colonial Development Act of 1929}

Before 1929, the British government did not have any specific law to grant the imperial financial assistance for the Protectorates. The imperial conference in 1921 and 1923 only agreed for a 
consensus to allocate financial assistance for colonies that includes Protectorates for a short period. Later, in 1928, Amery proposed to Churchill, the Chancellor of the Exchequer (1924-1929) to speed up the development in the Colonies and Protectorates for increasing employment in Britain. Amery forecasted that the trade depression and unemployment; especially in the heavy industries, not a temporary situation, which must be regarded as an economic factor of some permanence. So, continuous policy needs to be implemented to tackle the depression phenomenon. Hence, he suggested Churchill probably a certain sum of money as a Colonial Development Fund for a series of years to meet the charges or development schemes in Colonies and Protectorates ( $T$ 161/291/S33978,ff1-7, 1928). Amery strategy likely close with the Chamberlain neomercantilism policy, but contrary Amery more stressed the developments within the colonies rather than Chamberlain, which focused so much on tariff reform (Grayson, 2006).

In 1929, the British government approved Amery's proposal for the colonial economic development scheme. The world trade depression that began in the same year favoured the situation when most British politicians abandon the free trade principle that followed for the past 70 years (Miners, 2001). On 30 April, Amery announced that the Colonial Development Fund would be set up to provide imperial assistance for the colonial development (Havinden \& Meredith, 2002). Even though the Conservative government lost in the 1929 election, Amery's policy retained by the Lord Passfield in the Labour government. During the second reading of the Colonial Development Bill, he assured the house that the bill was essential to facing Britain's lamentable employment condition. To boost the job opportunities, the British export trade required to be stimulated by accelerating possible developments of Crown Colonies, Protectorates and Dependencies (Malaya Tribune, 1929b). At the same time, Amery also taking part on the bill debate, he emphasized that Malaya also needs the loan to proceed the hydro-electric scheme to overcome the malaria transmission, which will affect the industrial development in the country (The Singapore Free Press and Mercantile Advertiser, 1929). As a result, the Colonial Development Bill became law on 26 July 1929 which later permitted the Secretary of States for Colonies to invite the colonial government's application. The Colonial Development Act established funds not exceeding $£ 1$ million in any year by Parliaments' vote, and the colonial government may apply either in the form of grant or loan with either in whole or part interest payable during the ten years of any loan raised by that government $(753 / 1348,1929)$.

The Colonial Development Advisory Committee (CDAC) was formed to coordinate each application for financial assistance from the colonial government through the Colonial Office in London (Meredith, 1975). The members of the committee consisted of six people from the business, finance and trade unions. Within 1929 to 1940, CDAC recommends the British government to granted total $£ 19.3$ million for assisting transport projects, public health, water supply and power in the Colonial Empire. The Treasury also rejected several CDAC recommendations because it only favours the colonial government interest, which does not directly contribute to Britain's economy (British Aid-5, 1964). It is because Section No. 1 of the Colonial Development Act stated that the recommendation of CDAC for grants or loans for the colonial government must promote commerce or industry in the United Kingdom. This includes the development project related to the promotion of scientific research; instructional and experimental science, developing methods and practice in agriculture and industry, organizing the cooperation and instructing the growing and marketing produce, encouraging adoption of machinery and equipment for cultivation, improvement in internal transport and communications, and others aspect relating to export economy in Colonial Empire $(753 / 1348,1929)$. Yet, to support the home industry, the colonial government bound to the Colonial Office regulation that all materials and 
equipment acquired by Colonial Development Fund need to be ordered or contracted through Crown Agents. This includes plans and machines used in the factory or industry must be made in the United Kingdom and insured by the British insurance company (HCO 1041/1930).

\section{Colonial development in Malayan pineapple industry}

The implementation of colonial development policy in Malaya was through Secretary of States for the Colonies invitation to the Governor of SS on 7 August 1929. Justifying the invitation, the Colonial Office persuaded the SS Governor to realized that the colonial government in Malaya would face the world depression that affected her staple products and depreciated the enterprises' operation. Thus, the Colonial Office instructed the Governor to design the Malaya's economic development plan for CDAC consideration (Sel. Sect. G. 1489/1929, 1929). In the early 1930s, CDAC suggested the British government to approve the imperial aid for Malayan pineapples industry. It was because of Malaya potential as a supplier for the United Kingdom's food market (SCH 753/1348). The colonial development on Malayan pineapple industry resulted in cheapest canned fruit production on the market. Consequently, Malaya became the leading supplier of the product for the "poor man's dish and found a ready market in the United Kingdom" (Grist, 1930).

In 1926, IEC suggested the colonial government in Malaya to increase fruit production because of the increasing foodstuffs demand in the United Kingdom. However, like the other Protectorates, Malaya faced lower cultivation standards and was less organized in the marketing system. At the same time, the United Kingdom faced a shortage of imported canned fruit and the United States of America's food products dominate the global market. Thus, to reduce the United Kingdom dependency on imported foreign canned fruit, the IEC encouraging the British government to develop canned pineapples in Malaya. It was because the Malayan products were relatively cheap other than foreign products. The strategy intended to lessen the Unites States' canned fruits bulk in the United Kingdom and made headway for Dominions' canned fruit imported to the mother country. To enhance the empire's export, IEC was also forcing the British government to encourage the consumption of empire canned fruits in the United Kingdom (CO 273/534/15, 1926).

In 1928, the Colonial Office exhibited the Malayan pineapple products at Imperial Fruit Show in Manchester. The exhibition demonstrated pineapple's cooking method as a publicity strategy to increase the demand in the British Empire. Therefore, the trade returns for exported Malayan pineapples increased to 58,692 tons in 1929, rising over 1928 of 21 per cent, while 80 per cent of its export go to the United Kingdom (Editorial, 1930). The promotion of the Malayan pineapple products continued at Birmingham's Imperial Fruit Show in 1929. The Malayan producers used the show to gain a good reputation by exhibiting the best Malayan fruits brands comparable with Hawaii's product (Grist, 1930). Furthermore, during Glasgow's Empire Exhibition in 1938, Malayan pineapple occupied a prominent position in the Malaya Court. The Department of Agriculture promotes the pineapple product by demonstrating the pineapple canning factory, pineapple plantation and canned products (Editorial, 1939).

Table 1 shows the total of the imported canned pineapples to the United Kingdom in 1924. Malaya was the leading supplier that contribute 80 per cent of canned pineapples for the mother country. Besides the British territories, the United States was the foreign country that most penetrated the United Kingdom market with 13.5 per cent import that equivalence with 83,645 hundredweight. Apart from pineapples, imported canned fruits chiefly consist of apricots, pears and peaches. In 1924 the main supply of these fruits came from foreign countries; the United States 
was the largest supplier with 87 per cent imported products in the United Kingdom. While even Australia became the most extensive empire supplier, she only contributes nearly 7 per cent (CO 273/534/15 1926).

Table 1. Source of United Kingdom supplies for canned pineapples in 1924

\begin{tabular}{lcc}
\hline \multicolumn{1}{c}{ Countries whence consigned } & Cwts. & Per cent \\
\hline United States & 83,645 & 13.5 \\
Hawaii & 1,829 & 0.3 \\
Other foreign countries & 479 & 0.1 \\
\hline \multicolumn{1}{c}{ Total from foreign countries } & $\mathbf{8 5 , 9 5 3}$ & $\mathbf{1 3 . 9}$ \\
\hline South Africa & 21,784 & 3.5 \\
British Malaya & 496,997 & 80.4 \\
Australia & 3,721 & 0.6 \\
Other British territories & 9,552 & 1.6 \\
\hline Total from British territories & $\mathbf{5 3 2 , 0 5 4}$ & $\mathbf{8 6 . 1}$ \\
\hline \multicolumn{1}{c}{ Total imports } & $\mathbf{6 1 8 , 0 0 7}$ & $\mathbf{1 0 0 . 0}$ \\
\hline
\end{tabular}

Notes: 1 hundredweight (cwt.) $=112$ pounds in the United Kingdom or 100 pounds in the United States.

After the Colonial Development Bill passed in 1929, the British government continued encouraging the development of pineapples industry in Malaya. Pineapple production became more important in Malaya global trade with increasing of export volume in 1929 amounted to 58,692 . The Malayan pineapples exported from Singapore valued at over $\$ 9$ million in 1929, representing the fifth largest export industry in the Peninsula. As a result, Malaya turns to the second-largest producer of canned pineapples in the world after Hawaii. The distinction between Hawaiian and Malayan canned pineapples are product quality and production costs. The Hawaiian canner aimed for a product of first-class quality with the high price in the market. However, the Hawaiian production caused a large amount of waste due to the fruit's rigorous selection. But, Malayan canner prioritised the cheap product with the incidence of cheap labour and cheap factories of a temporary nature (Grist, 1930). However, Malaya's colonial government only considered the pineapple cultivation as a catch crop and retained rubber as the primary crops (Editorial, 1930).

Table 2 displays Colonial Development Funds' total provision to Malaya from 1931 to 1934, which assisted mostly by grants. Generally, the data shows that the UMS was the most undeveloped states requiring more financial assistance other than FMS and SS. Within 1932 to 1934, the British government granted the development funds for the FMS based on the recommendation of CDAC that urged the improvement of canning methods in the pineapple industry. The funds were expected to appoint a research chemist with experience in fruits canning to undertake three years' research into the best methods and conditions for canning pineapples. The bulk of the area devoted to pineapples production situated in Johore (approximately 40 thousand acres) and 11 thousand acres each in FMS and SS (SCH 753/1348). Continuing the tropical products research development in 1934, the Director of SS \& FMS Agriculture Department applied the Colonial Development Funds to conduct research on new varieties of a tropical plant that can be planted in Malaya. Thus, the FMS government applied a total of $\$ 13,573$ to conduct research on pineapples. From the amount, the government allocated $\$ 7,200$ to pay the emoluments of the chemical researcher and $\$ 3,333$ used to finance the research facility's development (Sel. Sect. G. 1489/1929, 1929). 
Table 2. Provision of Colonial Development Funds to Malaya

\begin{tabular}{ccccccc}
\hline \multirow{2}{*}{ Political Units } & \multicolumn{2}{c}{ Year 1931-1932 } & \multicolumn{2}{c}{ Year 1932-1933 } & \multicolumn{2}{c}{ Year 1933-1934 } \\
\cline { 2 - 7 } & Loans & Grants & Loans & Grants & Loans & Grants \\
\hline FMS & No & No & No & $£ 505$ & No & $£ 505$ \\
UMS & $£ 8,300$ & $£ 8,300$ & $£ 8,300$ & $£ 8,300$ & $£ 8,300$ & $£ 8,300$ \\
SS & No & $£ 6,000$ & No & $£ 6,000$ & No & $£ 6,000$ \\
\hline Total & $£ 8,300$ & $£ 14,300$ & $£ 8,300$ & $£ 14,805$ & $£ 8,300$ & $£ 14,805$ \\
\hline \multicolumn{3}{c}{ Source: SCH 753/1348 } & & &
\end{tabular}

In 1939, the Department of Agriculture of SS and FMS built a canning factory in Johor Bahru. The factory became the first government research station that used new canning machines ("Quarterly Report," 1939). It was because, up to 1935, the Malayan pineapple industry still used the hand-labour method to cane the fruit. During the period, the mechanized peeling and slicing not suitable for local canning ("Malayan Fruits," 1935). The department also controlled all factories through the Central Board of Pineapple Packers formed in the same year. Besides researched pineapple development, the Central Board manipulated the market by imposing a quota on each factory's production. In May 1939, the Central Board made an increase in the price of 15 cents per case on all grades of pineapples. Thus, the price per case increased from $\$ 3.10$ to $\$ 3.25$ for 1.5 lbs. standard cube ("Quarterly Report," 1939).

After the Ottawa Agreement in 1932, the British government implemented the imperial preference throughout the empire. Therefore, the colonial government in Malaya imposed protective tariff in imported Malayan canned food. All the foreign imported canned food charged with 15 per cent ad valorem in addition to the duty on the sugar content, while British and empire canned fruit pay no duty except on the sugar content. The protection stimulated the exportation of canned pineapples from Malaya to the United Kingdom, as reported in Table 3. Also, the increases in imported canned pineapple caused by the growth of consumption in the United Kingdom. Besides, the demand for Malayan canned pineapples due to the low price at which it sold. Tempany (1935) proved that $0.45 \mathrm{~kg}$ of Golden Yellow cubes in slices from Malaya retailed in the shop at 4.5 pennies each and 3.5 pennies for the lower grades. Compared to Australian canned pineapple sold at 11 pennies to 1 shilling, 1 penny for $0.45 \mathrm{~kg}$ (approximately to 1 pound-lb.), and Japanese from 5 pennies for $0.45 \mathrm{~kg}$ per tin.

Table 3. Imports of canned pineapples into the United Kingdom

\begin{tabular}{lcccccc}
\hline \multicolumn{1}{c}{ Exporting Countries } & $\mathbf{1 9 2 8}$ & $\mathbf{1 9 2 9}$ & $\mathbf{1 9 3 0}$ & $\mathbf{1 9 3 1}$ & $\mathbf{1 9 3 2}$ & $\mathbf{1 9 3 3}$ \\
& \multicolumn{2}{c}{ (in thousands of hundredweights) } & \\
\hline Malaya & 515 & 648 & 608 & 676 & 891 & 711 \\
Union of South Africa & 12 & 13 & 4 & 5 & 4 & 4 \\
Other Empire Countries & 1 & No & 2 & 3 & 17 & 19 \\
United States & 48 & 58 & 40 & 35 & 32 & 22 \\
Hawaii & 49 & 44 & 38 & 47 & 19 & 25 \\
Other Foreign Countries & 5 & 3 & 6 & 3 & 2 & 12 \\
\hline Total Empire Countries & $\mathbf{5 2 8}$ & $\mathbf{6 6 1}$ & $\mathbf{6 1 4}$ & $\mathbf{6 8 4}$ & $\mathbf{9 1 2}$ & $\mathbf{7 3 4}$ \\
\hline Total Foreign Countries & $\mathbf{1 0 2}$ & $\mathbf{1 0 5}$ & $\mathbf{8 4}$ & $\mathbf{8 5}$ & $\mathbf{5 4}$ & $\mathbf{5 9}$ \\
\hline \multicolumn{1}{c}{ Grand Total } & $\mathbf{6 3 0}$ & $\mathbf{7 6 6}$ & $\mathbf{6 9 8}$ & $\mathbf{7 6 9}$ & $\mathbf{9 6 6}$ & $\mathbf{7 9 3}$ \\
\hline
\end{tabular}

Source: Tempany (1935)

Notes: 1 hundredweight $(\mathrm{cwt})=$.112 pounds in the United Kingdom or 100 pounds in the United States. 


\section{Conclusion}

The development of Malayan pineapples industry was determined by colonial development policy to obtain the cheapest foodstuffs for the United Kingdom. The policy aimed to speed up the production to meet the demand in the mother country. In the early 1920s, the financial support for the development initiated by the Colonial Office. After the 1923's Imperial Conference, the British government began established empire cooperation in developing foodstuffs. The conference agreed to form the Imperial Economic Committee, which later inaugurated in 1925. The committee played a significant role in coordinating economy partnership within the British Empire by identifying a market for the Colonial Empire's food products and increasing its consumption in the United Kingdom. The committee identified Malaya possessed potential in developing pineapples industry that got a demand in the global market. Besides, the development of that industry also the imperial economic strategy to compete with the same product from Hawaii.

The impact of colonial development policy on Malayan pineapples industry had shown empirically in this article. The study found that Malaya became the major exporter for the cheapest canned pineapples in the global market. This consequence attributed to Leo Amery's policy that believed Britain would benefit by developing the colonies. This policy was a continuation of the neomercantilism policy by Joseph Chamberlain that depended on the Colonial Empire for the supply of raw materials and foodstuffs. Since 1927, Amery focused on tropical development in the Colonial Empire to accelerate the production in making the colonies a supplier for the temperate zones. Thus, the British government intervention in the colonial economy became more extent. In 1929, the British parliament passed the Colonial Development Act. Under this law, the British government granted imperial aid to finance the research and modern machinery for colonies economic development. In doing so, the Colonial Office instructed the colonial government in Malaya applied for the imperial support through the Colonial Development Advisory Committee to develop the pineapples industry. The Department of Agriculture used the funds to carries out research on pineapples plantations and production method, which centred in Johor.

\section{Acknowledgement}

This article is part of the author's $\mathrm{PhD}$ research jointly sponsored by Malaysia Ministry of Higher Education and Universiti Kebangsaan Malaysia in 'Hadiah Latihan Skim Latihan Akademik Bumiputera' (SLAB). No. 438/2018.10. We would like to thank you to the two anonymous reviewers for the advice and recommendation.

\section{References}

753/1348. (1929). Colonial Development Fund - Telegram from the Secretary of States Inviting Application for Assistance from: Colonial Development Advisory Committee.

Ashton, S.R. \& Stockwell, S.E. (1996). Imperial Policy and Colonial Practice 1925-1945. Series A, 1,1. London, HMSO.

Azlizan Mat Enh \& Salbiya Jamaluddin. (2020). Pentadbiran British di Sabah: Kesejahteraan Anak Negeri melalui penubuhan Mahkamah Anak Negeri 1884-1965. GEOGRAFIA: Malaysian Journal of Society and Space, 16(1), 155-167.

British Aid-5. (1964). Colonial Development. England, The Overseas Development Institute Ltd. 
CAB 24/158/CP/90. (1923). Proposal for Financial Assistance to Accelerate the Development of Imperial Resources, Joint Memorandum by the Secretary of State for the Colonies and the President of the Board of Trade, 8 February.

CO 273/534/15. (1926). Report of the Imperial Economic Committee on Marketing and Preparing for Market of Foodstuffs Produced in the Overseas Parts of the Empire.

CO 885/29/6. (1927). Colonial Office Conference, 1927. Memoranda and papers.

Collin, W.J. (2018). Publishing Economic History. In Blum, M. \& Colvin, C.L. (eds.), An Economist's Guide to Economic History (pp. 347-353). Switzerland, Palgrave Macmillan.

Constantine, S. (1984). The Making of British Colonial Development Policy 1914-1940. London, Frank Cass.

Drabble, J.H. (1974). Some thoughts on the Economic Development of Malaya under British Administration. Journal of Southeast Asian Studies, 5(2), 199-208.

Drummond, I. A. (1974). Imperial Economic Policy 1917-1939: Studies in Expansion and Protection. London, George Allen \& Unwin Ltd.

Editorial. (1930). Malayan Pineapples. The Malayan Agricultural Journal, XVIII (2), 60-61.

FMS. (1936). Annual Report on the Social and Economic Progress of the People of the Federated Malay States for 1935. Kuala Lumpur, FMS Government Press.

Godden, C. (2015). Economic History. International Encyclopedia of Social \& Behavioral Sciences, (2 ${ }^{\text {nd }}$ ed.), 7, 51-54. Elsevier. https://doi.org/10.1016/B978-0-08-097086-8.621098

Grayson, R. S. (2006). Imperialism in Conservative Defence and Foreign Policy: Leo Amery and the Chamberlains, 1903-39. The Journal of Imperial and Commonwealth History, 34(4), 505-527.

Grist, D.H. (1930). The Malayan pineapple industry. The Malayan Agricultura; Journal, XVIII (4), 188-191.

Havinden, M., \& Meredith, D. (1993) Colonialism and Development: Britain and its Tropical Colonies 1850-1960. London, Routledge.

HCO 1041/1930. Schemes Under Colonial Development Act.

Imperial Conference 1923. (1924) Appendices to the Summary of Proceedings, Ottawa.

Jessop, D. (1976). The Colonial Stock Act of 1900: A Symptom of the New Imperialism? The Journal of Imperial and Commonwealth History, 4(2), 154-163.

Loh, W. L. (2002). The Colonial State and Business: the Policy Environment in Malaya in the Inter-War years. Journal of Southeast Asian Studies, 33(2), 243-256.

Madden, A.F. (1959). Changing attitudes and widening responsibilities, 1895-1914. In Benians, E.A., Butler, J.R.M., Mansergh, P.N.S. \& Walker, E.A. (Eds.), The Cambridge History of the British Empire: Vol. III: The Empire-Commonwealth 1870-1919 (pp. 339-397). Cambridge, Cambridge University Press.

Malaya Tribune. (1928). Mr Ormsby-Gore Feted Speech at S.S.A. Dinner. Policy of Colonial Office.

Malaya Tribune. (1929a). A United Malaya ? Plea for Revision of the Constitution.

Malaya Tribune. (1929b). Loans for Colonies.

Meredith, D. (1975). The British Government and Colonial Economic Policy, 1919-39. Economic History Review, 28(3), 484-499.

Miners, N. (2001). Industrial Development in the Colonial Empire and the Imperial Economic Conference at Ottawa 1932. Journal of the Hong Kong Branch of the Royal Asiatic Society, 41, 1-24. 
Mokhtar, M.S. (2019). Di sebalik krisis kewangan Negeri-Negeri Melayu Bersekutu, 1920-1924. Kajian Malaysia, 37(2), 95-119. https://doi.org/10.21315/km2019.37.2.5

Mokhtar, M.S., Samsudin, M., \& Azmi, M.A.A. (2017). Perkembangan sistem perdagangan merkantilisme Negeri-Negeri Melayu Bersekutu (1909-1913). Jebat: Malaysian Journal of History, Politics \& Strategic Studies, 44(2), 1-26.

New Zealand. (1921). Conference of Prime Ministers and Representative of the United Kingdom, the Dominions, and India (Summary of Proceedings and Documents of the), Held in June, July and August 1921, at London Journals of the House of Representatives, I-II.

New Zealand. (1927). Imperial Conference, 1926. (Summary of Proceedings). Journals of the House of Representatives, I, A-06.

Osterhammel, J. (2014) The transformation of the world: A global history of the nineteenth century. Princeton, Princeton University Press.

Palen, M.W. (2016). The "Conspiracy of Free Trade”: The Anglo-American Struggle Over Empire and Economic Globalisation, 1846-1896. Cambridge, Cambridge University Press.

SCH 753/1348. Colonial Development Advisory Committee, Interim Report.

Sel. Sect. G. 1489/1929. (1929). Colonial Development Act. 1929, Procedure Governing the Submission of Applications by Colonial Government for Assistance from the Colonial Development Fund.

Sultan Nazrin Shah. (2019). Striving for inclusive development: From Pangkor to a modern Malaysian State. Kuala Lumpur, Oxford University Press.

T 161/291/S33978, ff1-7. (1928) Colonial Development: letter from Mr Amery to Mr Churchill on measures to increase employment in the UK and proposing the establishment of a colonial development fund.

Tempany, H.A. The trade in canned fruits in the United Kingdom. The Malayan Agricultural Journal, XXIII (4), 164-171.

The Singapore Free Press and Mercantile Advertiser. (1929). Colonial Development.

Tomlinson, B.R. (2003). The British economy and the Empire, 1900-1939. In Wrigley, C. (Ed.), A Companion to Early Twentieth-Century Britain (pp. 198-211). Oxford, Blackwell Publishers Ltd.

Tomlinson, J. (2012). The Empire/Commonwealth in British Economic Thinking and Policy. In Thomson, A. (Ed.), Britain's Experience on the Empire in the Twentieth Century (pp. 211250). Oxford, Oxford University Press.

Wong, Lin Ken. (1979). Twentieth-Century Malayan Economic History: A Select Bibliographic Survey. Journal of Southeast Asian Studies, 10(1), 1-24. 